\title{
Discovering Intercultural Citizenship through Virtual Realia: The United Kingdom and Spain in the 1793 British Press ${ }^{1}$
}

\author{
María Jesús Lorenzo-Modia \\ Universidade da Coruña
}

Received: 8 May 2015 / Accepted: 20 May 2016

ISSN: $1697-7467$

\begin{abstract}
This paper explores ways in which intercultural citizenship can be investigated by students through the use of both archival material and extracted information from the daily press, now widely accessible in databases, and how to convey the significance of transcultural exchange and historical events to students of English language and cultures at the university level. The theoretical framework employed is that of the relationship between language and identity, in which international events are contextualized through their effects on the daily lives of citizens. Additionally, the cultural, economic and political exchanges between the Iberian Peninsula and the United Kingdom described in these documents prove instrumental in the formation of present-day students' identity, as well as raising their critical intercultural awareness.
\end{abstract}

Keywords: Intercultural citizenship, virtual realia, Spain, United Kingdom, 1793.

Enseñando ciudadanía intercultural mediante materiales auténticos: el Reino Unido y España en la prensa inglesa del año 1793

RESUMEN: Este trabajo muestra un ejemplo de investigación del concepto y praxis de la ciudadanía intercultural mediante el uso de documentación archivística e informaciones de prensa procedentes de bases de datos accesibles para los docentes del siglo XXI, con el fin de que el estudiantado universitario de lengua y culturas inglesas pueda conocer intercambios transculturales y acontecimientos históricos. El marco teórico utilizado es la relación entre la lengua y la identidad mediante la que estos eventos aparecen contextualizados en la vida diaria de la ciudadanía. Además, los intercambios culturales, económicos y políticos presentes en los documentos citados resultan de gran utilidad para incrementar la conciencia crítica intercultural del estudiantado actual, así como la formación de su propia identidad.

Palabras clave: Ciudadanía intercultural, materiales auténticos virtuales, España, Reino Unido, 1793.

${ }^{1}$ This paper has been possible thanks to the research networks (R 2014/043) funded by the Galician Government (Xunta de Galicia) and the European Regional Development Fund (ERDF), and FFI2015-71025-REDT, and to the research projects FFI2012-35872, and FEM2015-66937-P funded by the Spanish Ministry of Economy and Competitivity (Ministerio de Economía y Competitividad). These grants are hereby gratefully acknowledged. 


\section{INTRODUCTION}

This paper addresses the use of both British newspapers and English and Spanish archival materials as didactic tools in the teaching of language and culture in a university setting, a practice which affords students access to authentic eighteenth-century materials through electronic twenty-first-century tools. Maritime relationships between Spain and the British Isles existed at the time through the ports of Corunna and Falmouth, and continued with minor interruptions for more than a century, reaching a peak after the French Revolution, when land-based communications through France were severely restricted for political and security reasons. The commercial and intelligence activities of the vessels were regularly reported in British journals, which also included information on the effects of revolutionary and other political activities in various European countries. With this in mind, the present study is made up of British newspapers published in the year 1793, thus allowing students to familiarize themselves with original eighteenth-century publications, as well as with the daily effects of a major history change, in this case the momentous events that took place in France the previous year.

Following M. Byram (2008), our contention is that by means of the use of these particular tools students establish an intercultural dialogue and communication that facilitates the acquisition of a social identity, one in harmony with those of others. Thus, by not promoting dominant social identities and values, their actions connect to democratic virtues. This approach in language teaching is closely associated to learning about one's own country through comparison, about otherness in our own land, and about how our respective identities are themselves perceived and respected. Ultimately, knowledge about history and being conscious of the values which are privileged within will make it more likely that students become committed to good practice in their activities beyond the educational environment.

\section{Theoretical Framework}

The use of authentic material in the foreign language classroom has been discussed previously (Celce-Murcia \& Hilles, 1988; Celce-Murcia \& Olshtain, 2000), and the use of virtual realia in particular is a direct consequence of technical evolution in the digital age (Smith, 1997; Hubbard \& Levy, 2006; Erben, 2013), constituting an especially fruitful and appealing option for university-level teaching of English language and culture (Williams and Lahaie, 2006). In recent years, the understanding of authenticity in the field of language teaching has been challenged (Gilmore, 2007) in light of translingual tendencies in linguistic practices (Canagajarah, 2010; 2013), perhaps best illustrated by the ecological metaphor for the study of language (e.g. Kramsch, 2002; Lankiewicz, 2015); nevertheless, authentic materials remain an invariable asset of any foreign language classroom. Methodological issues here also draw heavily on the sociocultural perception of the relation between language and identity "conventionally linked to epistemic and affective stances" (Ochs, 1996: 424). Hence, we can maintain that direct contact with the carriers of cultural messages, such as newspapers, has a significant impact on identity formation and critical intercultural awareness (Byram, 2008). 


\section{Corpus Selection}

The materials used are restricted to the English newspapers published in the year 1793, as it is in this period of turmoil that the situation in France is first reported consistently in the press. These digitized texts are accessible through a collection of seventeenth- and eighteenth-century London newspapers, originally compiled by Dr Charles Burney, held by The British Library, and distributed by Gale Cengage. Other archival sources from Spanish and British institutions, such as the Public Record Office, the Archivo General de Simancas, and the Archivo Histórico Nacional, are also provided so as to afford students access to authentic materials other than news releases, these not currently accessible on the Internet. The selection of the topic is also influenced by the idea that learning through daily events, as reflected in the press, is a necessary complementary activity for us as a means of understanding relevant changes in our civilization, such as that of the fall of the Bastille and its tumultuous aftermath.

\section{Antecedents}

The connection between Galicia and the British Isles probably has its origins in preRoman times, and can be traced back to the history of Mil and the Milesians, who set sail from the port of Corunna and conquered Ireland, as recounted in the Leabhar Gabhála na hÉireann (de Toro Santos, 2000; Álvarez Lugrís and Moscoso Mato, 2005). According to this ancient source, also known as the Book of Invasions, the prehistoric Galician mythic king Breogán was the father of Ith, leader of the first Celtic expedition to Ireland from the Iberian Peninsula. This relationship between the British Isles and Spain persisted throughout the centuries. In particular, the Age of the Enlightenment saw an intense cultural, political and economic exchange between the two countries (Lorenzo-Modia, 2002, 2013), albeit not always amicable. Illustrious visitors — such as the poet Robert Southey, the preacher George Borrow, and Lord and Lady Holland, to name but a few- used this maritime link as a convenient means of transport to Iberia. Indeed, there was a regular Falmouth-Corunna packet boat service between the years 1689 and 1815, which well illustrates the significant historical link that existed here throughout the long eighteenth century (Meijide, 1966).

\section{Analysis}

The relationship between Spain and England is itself a significant one, but becomes decisive as a result of the European turmoil caused by revolutionary France. The execution of Louis XVI on January 21, 1793, and France's policy of territorial annexation, triggered a huge sense of outrage throughout Europe. With the declaration of war on Great Britain and the Low Countries, issued by the French Revolutionary Government on February 1, 1793, the year saw the commencement of more than two decades of military conflict between France and Britain, including the French Revolutionary Wars (1793-1802) and the Napoleonic Wars (1803-1815). Likewise, on March 7, France declared war on Spain, "encouraged 
by the weakness of Spain's defences and the disorder of its government" (Lynch, 1989: 389). These conflicts with France meant the end of the balance of power in Europe which had persisted throughout the Age of Reason. Most European countries (with the exception of Sweden, Switzerland, Venice, Denmark, and Turkey) formed an anti-French military coalition. For Britain and Spain, the expected consequence was an alliance between both countries, although, as John Lynch points out, "Relations were uneasy from the beginning" (1989: 390). References to these events can be read in the English press of the period, in connection to Galicia:

Madrid, FEB. 1. A courier, who arrived yesterday from Paris, brought intelligence hither of the death of Louis XVI. Great consternation was immediately spread throughout this capital, all the places of public amusement were immediately shut; solemn service was ordered for the 4th in the Chapel Royal, and will be performed in all the churches of the capital and kingdom. Great preparations are continued; and orders are dispatched to Ferrol and Corunna to hasten the works going forward there. No one doubts here that a treaty, defensive and offensive, has been concluded between our Court and England. (Star, 1, 505, Saturday, February 23, 1793).

In this war context, once France ceased to be a feasible route for commerce or travel between England and Iberia, and due to the "very uncertain and circuitous" Lisbon route - as noted by Lord St. Helens, the British Ambassador to Madrid-, the city of Corunna became a key port, insofar as the eighteenth-century packet boat communications between the peninsula and the British Isles remained open (Historical 409). A regular postal sea line, called the Corunna Boat or the Spanish Packet, which connected Corunna with Falmouth, existed from the end of the seventeenth to the beginning of the nineteenth century. However, according to Meijide (1966), the official transportation of mail was suspended four times in the eighteenth century, during the various wars in which Spain and the United Kingdom were involved: the first of these was during the War of Spanish Succession 1701-1713, affecting the regularity of the boat until 1716; the second interruption ran from 1739 to 1749 , corresponding to the War of Jenkins' Ear between Spain and Britain, as part of the War of the Austrian Succession; the Spanish Packet also ceased sailing to England between the years 1763 to 1793 as a consequence of the Seven Years' War (1756-1763), related to the rivalry for colonial supremacy in North America; and finally the Corunna Boat suffered interruptions between 1804 and 1808 during the Napoleonic wars in which Spain fought against England (Meijide, 1966: 45) although it did not stop entirely during these periods, as explained below.

Trade depended on the international political situation and was vulnerable to its fluctuations. Abundant mention of the necessity of this sea link appears in both British and Spanish official documents of the period, for example in a memorandum sent to the British Council of Trade by London merchants in 1792, which alluded thus to the French political situation: "[a] nation under a new form of government apparently very unsettled and actually engaged in war", and stated that "the direct conveyance of the commercial correspondence to and from Spain, independent of France, is a measure very much to be desirable at all times and more especially in the present situation of France" (Public Record Office, 21 June 1792. Foreign Office. Spain. Ms. 353/49). The boat in question provided facilities for 
the exchange of passengers, goods, plus news and opinions, to the extent that information about Galician products of the time could be found in English periodicals and newspapers, and even praised by travellers; Galician Cebreiro cheese, for instance, was very favourably described in The Lady's Magazine (Oct. 1770: 130-32). The type of information provided in the British press ranges from an interest in re-establishing the regular boat service to the description of the Spanish city of Corunna and its monuments. The transport of goods would at times be restricted to a minimum in order to avoid problems with the French Men-of-War, as we can read in the Proceedings of the Real Consulado of Corunna for 31 May, 1798: "para evitar qualquiera [sic] compromiso que pudiera ofrecerse con las Naves de Guerra francesas" (in order to avoid any predicament that might arise with the French Men-of-War) (Book 2, 123). Through the packet service, information was also obtained via Corunna about the French regime, which sometimes reached Britain more easily from here than from other European cities.

The various interruptions of the packet boat service, together with the type of exchanges which the service itself brought, will be identified by the students here mainly by means of references in the British press from the year 1793, a moment in which, as mentioned above, France declared war on Britain and Spain, and which saw the establishment of an alliance between these two countries. Obviously, this fact marked a British interest in the Spanish boat as a means of communication, due to the interruption of the sea connection with France and the Dutch provinces.

Regarding the existence of the Spanish Boat, it must be noted that this service in fact seemed to continue even during the years in which Meijide Pardo indicated that it was suspended. For example, there is evidence in the English periodical press that packet boats reached different ports in the South of England, such as London, Ramsgate, Gravesend, and Plymouth, between the years 1789 to 1793. These ships transported merchandise (Public Advertiser, 17635, Thursday, Jan. 13, 1791; Public Advertiser, 17866, Monday, Oct. 10, 1791), as can be seen in the following extract: "Wind W.N.W. came in for shelter, the Buxton, Robert Scott, of Yarmouth, from London to Corunna, with merchandise" (Diary or Woodfall's Register, 1129, Friday, Nov. 2, 1792). The British interest in re-establishing the sea link was not shared with equal enthusiasm by the Spanish authorities, due to the open smuggling of goods, coin, and silver, considered to be in clear detriment to Spanish interests. The Spanish Ambassador to London wrote to Prime Minister Manuel Godoy in the following terms: "ofensiva a la soberanía del Rey y perjudicial a sus reales intereses" (offensive to the sovereignty of the King and prejudicial to his royal interests) (Archivo Histórico Nacional 12, and 14 June, 1795. Estado. Leg. 4.216). Further information on the same lines can be found at the Archivo General de Simancas, 14, 17, 26 September 1794 (Secretaría de Estado. Leg. 8.154). Although it cannot be denied that passengers, commodities, and some mail could have been carried on board in previous years, the postal service was officially restored in June 1793:

Packet-boats being established between Falmouth and Corunna, in order to carry on a weekly correspondence between Great Britain and Spain, a Mail will be made up and dispatched from hence every Friday night, with the letters for Spain, by which the letters for Oporto [sic] will also be forwarded, unless they are directed Via Lisbon (London Chronicle, 5749, Saturday, June 22, 1793). 
In fact, the arrival of the first official mail from Corunna is also reported in the London press: "On Wednesday arrived, at the General Post Office, a mail from Corunna, which was brought over in his Majesty's new packet the King George, after a fine passage of only four days to Falmouth. She is the first packet that has arrived since the commencement of the conveyance of letters from that quarter" (Public Advertiser, 18410, Friday, June 14, 1793). The interest of the British Government in establishing this mail packet boat line was so great that in February it had appointed the Ambassador himself, Lord Saint Helens (1753-1839) (Prideaux Courtney, 1975: 695) (Diary or Woodfall's Register, 1222, Tuesday, February 19, 1793) as the person in charge of opening negotiations with the Spanish Crown, who at the time was reluctant:

One of the first objects of Lord St. Helen's embassy to Madrid was to establish a communication between Corunna and Falmouth. It was in consequence of this, that Lord Grenville could not comply with the wishes of the Merchants for the immediate establishment of a packet between the two places during the war. The Spanish Government is extremely unwilling to adopt the plan, and has on former occasions given forcible reasons for the request not being granted, particularly as it would open the channel of smuggling Spanish coin into this country (Lloyd's Evening Post, 5589, Wednesday, April 17, 1793).

This item of news had such an impact that even the names of the two vessels contracted by the English for this service, the Arab and the Janverin, were provided by the newspapers (Sun 197, Friday, May 17, 1793). In June, probably due to the necessity of maintaining the regularity of the service, "the Post-Masters General [...] appointed his Majesty's new packet, the Ariel, to carry over the mail for Corunna" (Diary or Woodfall's Register, 1316, Monday, June 10, 1793). There were also some other British and Spanish vessels involved, respectively King George, Reina Luisa, and La Angelanne, since Spain finally agreed to cooperate in the regular running of the line:

The Spaniards on their compact to partake an equal share of the expence and risque of conveying the letters to and from Spain and Great Britain, have appointed two packet-boats in addition to those appointed by the British Post Masters to pass between Falmouth and Corunna during the war. The Spanish packets are $L a$ Reigna Louisa and La Angelanne [sic]. (General Evening Post, 9348, Thursday, August 22, 1793).

In the press news of 1793, the occasional change of the British port of call, from Falmouth to Plymouth, can also be traced (General Evening Post 9354, Tuesday, Sept. 17, 1793). It might be recalled here that this change remains effective to the present day, in that a regular ferry boat service exists from Santander (the Northern Spanish city which replaced Corunna in this activity) to Plymouth.

Moreover, as the year progressed the British brought two additional packets into commission, which indicated the significance of this means of communication for intelligence information between the Navy in the Mediterranean and the Admiralty in London (Lloyd's Evening Post 5654, Monday, Sept. 16, 1793). According to information published in the General Evening Post 9354, 9365, Tuesday, Sept. 17, and Oct. 1793, dispatches were delivered to and from 
Lord Samuel Hood (1724-1816), Admiral of the British Navy in the Mediterranean (Knox Laughton, 1975: 998) and the Admiralty Office by means of the Corunna Boat. The same news item indicated that correspondence and intelligence from the Mare Nostrum was sent to Britain via Corunna from Barcelona, due to the impossibility of sending messages through France (Lloyd's Evening Post 5654, Monday, Sept. 16, 1793). The importance of this means of communication through the Corunna Boat is beyond any doubt, since it is publicly reported that in order to ensure that official intelligence documentation reached its destination, various procedures were devised, one of these definitely being the Corunna Boat. Evidence found in the State Papers of the Public Record Office show that reports in code were sent from Cádiz to London via the Corunna packets (Spanish Consuls, Mss. 94/182 to 94/254). On some occasions, British readers learn that Lord Samuel Hood's dispatches from the Mediterranean were sent to England via Italy and their duplicates by way of Corunna (St James's Chronicle or the British Evening Post, 5075, Saturday, Sept. 14, 1793). Additionally, dispatches for Hood at Toulon, sent from the Admiralty Office, went "by way of Falmouth to Corunna and overland through Spain"; and they were also "dispatched from Plymouth by a cutter through the Mediterranean" (General Evening Post, 9365, Thursday, Oct. 10, 1793). It must be remembered that both the Spanish and the British navy were participating in the siege of Toulon, and the British Admiral, Lord Hood, kept his government informed via Corunna. Lord Hood (1724-1816) and Juan de Lángara (Corunna c.1736-1806), admirals of the two fleets, succeeded in taking this Mediterranean French city in August 1793. The French, though, regained Toulon in December thanks to the presence of an unknown artillery commander, Napoleon Buonaparte, who rose to prominence after this victory, with his surname newly spelled as Bonaparte.

On April 17, 1793, the Spanish carabineers commanded by General Antonio Ricardos (1727-1794), who was of British origin (Richards), occupied the French region of Roussillon unexpectedly. Reports of this action, together with some dreadful data concerning the Terror in France, were also published in the British press via Corunna:

The Corunna Mail which arrived on Wednesday, brought intelligence of a dreadful nature from the province of Roussillon: the Convention, in order to stop the progress of the Spaniards in the neighbourhood of Perpignan, ordered that the tremendous guillotine should be carried to every city, borough, and village of the country, to an immense extent. The French compelled every inhabitant, from the age of 12 to 60, under pain of death, to join the Republican army; killing such as refused to serve, and (horrible to tell!) 500 heads of families refusing to bear arms, were put to death at Perpignan! The Spaniards, apprehending the most fatal consequences from such barbarians, were forced to retreat; and when the last advices came away, they were at only four leagues distance from their own frontier (Lloyd's Evening Post, 5676, Wednesday, Nov. 6, 1793).

During the war, an illustrious visitor, Alexander Jardine (1736-1799), came to Spain via Corunna. A military man, an intellectual, and a spy, he had been appointed consul in this city in 1793, travelled to Spain that year to take up his position, and hence to continue with his diplomatic activities. However, he and his family were captured by the French when they were sailing from Falmouth to Corunna. The St. James's Chronicle or the British Evening Post 5601 reports this piece of news on Thursday, Nov. 14, 1793: "news had reached 
Corunna $[\ldots]$ that the El Quiros, a Spanish packet, which sailed from Falmouth on the $16^{\text {th }}$ ult. was captured by a French frigate. Among the passengers taken and carried to France was Mr. Jardin [sic], who was going out Consul-General to Corunna, with his family". The World also reproduces Alexander Jardine's capture by the French while sailing to Corunna, noting his previous post as Consul in Barbary (Morocco) and his well-known book entitled Letters from Barbary, France, Spain, Portugal, \&c, published in 1788 (2152, Wednesday, Nov. 20, 1793). In fact, after being seized by the French, the El Quiros was boarded by the privateer James and Nancy, and the passengers had to pay a substantial ransom to be liberated (Pérez Berenguel, 2001: 59). According to Jardine's letters, he arrived safely in Gijón on November 5, and from there he proceeded to Corunna (Pérez Berenguel, 2001: 59); nevertheless, the English press provided a different version:

Major Jardine and family, who were taken in a Spanish packet by a French privateer, on his passage to Corunna, where he was appointed his Majesty's Consul, are since arrived safe in Spain; the packet in which they were, having been recaptured within forty-eight hours by the Alphonsa Spanish frigate, and carried safe into Corunna (London Chronicle, 5814, Tuesday, Nov. 19, 1793; London Packet or New Lloyd's Evening Post, 3787, Wednesday, Nov. 20, 1793).

As we have already noted, the presence of foreigners was instrumental in the development of the identity of the city, and after their visits travellers also reported news and accounts about Corunna and its landmarks. In the eighteenth century, and indeed at the present time, the city's most notable monument is the Roman lighthouse known as Hercules Tower, named a World Heritage Site in 2009. It seems that eighteenth-century visitors were impressed by the monument and its rebuilding in the last decade of that century, and reported on its historical importance and its usefulness for navigation, together with the enlightened citizens and societies who contributed to its reconstruction:

Corunna, to which the packets sometimes sail from Falmouth in four days, is a place of importance to Antiquarian travellers, on account of a tower, which the "Cronica General" supposes to have been built by the Egyptian Hercules, and to have contained a mirror, in which vessels might be descried at a great distance. The Academy of History at Madrid have just desired D. Joseph Cornide to prepare an inscription in Latin and Spanish for the tower, and to favour them with his collection concerning it. (London Packet or New Lloyd's Evening Post, 3793, Friday, December 6, 1793).

To sum up, a review of the British press of 1793 shows that the connections between Corunna and England are reinforced in this period through the re-establishment of the packet boat service and the exchange of merchandise, passengers, news and ideas, which contributed to the progress of this city and, subsequently, of both countries. In addition, the Corunna Boat became of considerable importance in the transport of both regular mail and intelligence at the beginning of the Revolutionary Wars in Europe, which was itself instrumental in the course of the Wars, especially two events: the siege of Toulon and the War of Roussillon. 


\section{Conclusion}

This study has been presented in the form of a lecture to students of English as a foreign language, as a means of constructing a cultural bridge in the use and understanding of historical perspective, and in the socio-ecological belief that language is never a neutral means of communication but rather a historically grounded and socially constituted habitus (Bourdieu, 1977). An insight into cross-cultural relations between the two countries, through the use of authentic newspaper entries, may help to facilitate a more critical approach to cultural knowledge, resulting in the promotion of the kind of informed, intercultural citizenship fit for the twenty-first century. The material offers mutually held perceptions, since " $(\ldots)$ who we are, who we think others are, and who others think we are, mediate in important ways our individual uses and evaluations of our linguistic actions in any communicative encounter" (Hall, 2002: 34). In this way, historical communicative encounters in a foreign language constitute a substrate to identify with in a geographical and cultural sense. Additionally, working on authentic material develops a capacity for critical language awareness since knowledge is not communicated propositionally; on the contrary, it is reconstructed from various sources and construed in a very individual way and, as Byram argues, "awareness that one's own values and ideological perspectives are culturally determined and that they may not be compatible with those of other people" (2008: 179) is ultimately crucial for developing intercultural citizenship.

The use of the daily press by means of virtual realia, namely databases, has proved to be a very powerful didactic tool which enhances students' linguistic and cultural abilities as well as their motivation for embarking on original research. The present review of the 1793 British press has been tested as an innovative project insofar as it analyses the early effects of the French Revolution in the city of Corunna and in Spain as a whole, and -additionally- the key role that maritime communications with the United Kingdom played in the long aftermath of the French Revolution in Europe. Benjamin S. Bloom's revised taxonomy of education objectives (1984) has also been useful in that all his six steps, from low to high knowledge, have been followed in the project (Anderson et al., 2001: 67-68). Students have learned not only the importance of cultural virtual realia as a form of expanding their knowledge and enhancing their understanding; they have also applied their knowledge to their own land using cognitive and linguistic skills together with analytical thinking. Finally, students have made a synthesis of conscious learning and the realisation that every place and person may be instrumental in history, and may take action in order to change it (Williams, 2006: 26-28).

\section{REFERENCES}

Álvarez Lugrís, A. and Moscoso Mato, E. (2005). "Galicia, Irlanda e o Leabhar Gabhala. O mito celta no proceso de construción da identidade nacional galega", in $\mathrm{M}^{\mathrm{a}} \mathrm{D}$. Gómez (coord.) A identidade galega e irlandesa a través dos textos. Galician and Irish Identity through Texts. Santiago de Compostela: Universidade de Santiago de Compostela, 55-131.

Anderson, L.W. et al. (eds.) (2001). A Taxonomy for Learning, Teaching, and Assessing: A Revision of Bloom's Taxonomy of Educational Objectives. Complete edition. New York: Longman. 
Bloom, B. S., Krathwohl, D. R., and Masia, B. B. (1984). Taxonomy of Educational Objectives. London: Longman.

Bourdieu, P. (1977). Outline of the Theory of Practice. Cambridge: Cambridge University Press. Byram, M. (2008). From Foreign Language Education to Education for Intercultural Citizenship: Essays and Reflections. Clevedon: Multilingual Matters.

Canagarajah, S. (2010). "Codemeshing in academic writing: Identifying teachable strategies of translanguaging", in Modern Language Journal 95, 3: 401-417.

Canagarajah, S. (2013). Translingual Practice. Global Englishes and Cosmopolitan Relations. New York: Routledge.

Celce-Murcia, M. and Hilles, S. (1988). Techniques and Resources in Teaching Grammar. Oxford: Oxford University Press.

Celce-Murcia, M. and Olshtain, E. (2000). Discourse and Context in Language Teaching. Cambridge: Cambridge University Press.

Diary or Woodfall's Register 1129, Friday, 2 November (1792), Gale Document Number: Z2000304523, available from: http://www.gale.cengage.com/DigitalCollections/products/ Burney/, accessed 20 October, 2014.

Diary or Woodfall's Register 1222, Tuesday, 19 February, (1793), Gale Document Number: Z2000305944, available from: http://www.gale.cengage.com/DigitalCollections/products/ Burney/, accessed 20 October, 2014.

Diary or Woodfall's Register 1316, Monday, 10 June (1793), Gale Document Number: Z2000307346, available from: http://www.gale.cengage.com/DigitalCollections/products/Burney/, accessed 20 October, 2014.

Dickens, M., Robertson, I., and Hofmann, E. (1995). Realia: Bringing the Real World into the Classroom [Online], available from: http://www.wlc.com/oxus/realia.htm, accessed 20 October, 1997.

Erben, T. (2013). Calling All Foreign Language Teachers. London: Routledge.

General Evening Post, 9348, Thursday, 22 August (1793), Gale Document Number: Z2000478208, available from: http://www.gale.cengage.com/DigitalCollections/products/Burney/, accessed 23 October, 2014.

General Evening Post, 9354, Tuesday, 17 September (1793), Gale Document Number: Z2000478328, available from: http://www.gale.cengage.com/DigitalCollections/products/Burney/, accessed 23 October, 2014.

General Evening Post, 9365, Thursday, 10 October (1793), Gale Document Number: Z2000478430, available from: http://www.gale.cengage.com/DigitalCollections/products/Burney/, accessed 23 October, 2014.

Gilmore, A. (2007). "Authentic materials and authenticity in Foreign Language Learning", in Language Teaching, 40: 97-118.

Hall, J.K. (2002). Teaching and Researching Language and Culture. Essex: Pearson Education. Historical Manuscripts Commission (1894). vol. 2. London.

Hubbard, P. and Levy, M. (2006). Teacher Education in CALL. Amsterdam: John Benjamins.

Jardine, A. (1788). Letters from Barbary, France, Spain, Portugal, \&c. 2 vols. London: T. Cadell.

Knox Laughton, J. (1975). "Hood, Samuel, Viscount Hood", in Edgar Williams (ed.), The Compact Edition of the Dictionary of National Biography. vol. 1. Oxford: Oxford University Press, 998 [1157-1164].

Kramsch, C. (ed.) (2002). Language Learning and Language Socialization. Ecological Perspectives. London and New York: Continuum.

The Ladies Magazine, October (1770). 
Lankiewicz, H. (2015). Teaching Language Awareness in the Ecological Perspective. Gdańsk: University of Gdańsk.

Libro de Actas (1798). A Coruña: Real Consulado de A Coruña.

Lloyd's Evening Post, 5589, Wednesday, 17 April, (1793). Gale Document Number: Z2000534165, available from: http://www.gale.cengage.com/DigitalCollections/products/Burney/, accessed 24 October, 2014.

Lloyd's Evening Post, 5654, Monday, 16 September, (1793). Gale Document Number: Z2000534722, available from: http://www.gale.cengage.com/DigitalCollections/products/Burney/, accessed 24 October, 2014.

Lloyd's Evening Post, 5676, Wednesday, 6 November, (1793). Gale Document Number: Z2000534903, available from: http://www.gale.cengage.com/DigitalCollections/products/Burney/, accessed 24 October, 2014.

London Chronicle, 5749, Saturday, 22 June, (1793). Gale Document Number: Z2000597527, available from: http://www.gale.cengage.com/DigitalCollections/products/Burney/, accessed 24 October, 2014.

London Chronicle, 5814, Tuesday, 19 November, (1793). Gale Document Number: Z2000598166, available from: http://www.gale.cengage.com/DigitalCollections/products/Burney/, accessed 24 October, 2014.

London Packet or New Lloyd's Evening Post, 3787, Wednesday, 20 November, (1793). Gale Document Number: Z2000748720, available from: http://www.gale.cengage.com/DigitalCollections/products/Burney/, accessed 26 October, 2014.

London Packet or New Lloyd's Evening Post, 3793, Friday, 6 December, 1793. Gale Document Number: Z2000748771, available from: http://www.gale.cengage.com/DigitalCollections/ products/Burney/, accessed 26 October, 2014.

Lorenzo-Modia, M. J. (2002). "Cultural relationships between Corunna and the English speaking countries in the late eighteenth century", in Elizabeth Woodward Smith et al. (eds.), Aspects of Culture. A Coruña: Servicio de Publicaciones de la Universidad, 159-170.

Lorenzo-Modia, M. J. (2013). "La función de la prensa británica en los conflictos anglo-hispánicos a comienzos del siglo XIX”, in F. Durán López (ed.), Hacia 1812 desde el siglo ilustrado. Gijón, Asturias: Trea y Sociedad española de estudios del siglo XVIII, 211-224.

Lynch, J. (1989). Bourbon Spain 1700-1808. Oxford: Basil Blackwell.

Meijide Pardo, A. (1966). Correos maritimos entre Falmouth y La Coruña (1689-1815). A Coruña: Instituto José Cornide de Estudios Coruñeses.

Ochs, E. (1996). "Linguistic resources for socializing humanity", in J. Gumperz and S. Levinson (eds.), Rethinking Linguistic Relativity. Cambridge: Cambridge University Press, 407-437.

Pérez Berenguel, J. F. (2001). "Introducción", in A. Jardine, Cartas de España. Alicante: Publicaciones Universidad de Alicante, 19-140.

Prideaux Courtney, W. (1975). "Fitzherbert, Alleyne, Baron St. Helens", in Edgar Williams (ed.), The Compact Edition of the Dictionary of National Biography. Vol. 1. Oxford: Oxford University Press, 695 [166-168].

Public Advertiser, 17635, Thursday, 13 January, (1791). Gale Document Number: Z2001215277, available from: http://www.gale.cengage.com/DigitalCollections/products/Burney/, accessed 26 October, 2014.

Public Advertiser, 17866, Monday, 10 October, (1791). Gale Document Number: Z2001219006, available from: http://www.gale.cengage.com/DigitalCollections/products/Burney/, accessed 26 October, 2014. 
Public Advertiser, 18410, Friday, 14 June, (1793). Gale Document Number: Z2001226376, available from: http://www.gale.cengage.com/DigitalCollections/products/Burney/, accessed 26 October, 2014.

Smith, B. (1997). "Virtual realia", The Internet TESL Journal III, 7 July, n. p., available from: http://iteslj.org/Articles/Smith-Realia.html, accessed 12 January, 2015.

St James's Chronicle or the British Evening Post 5075, Saturday, 14 September, (1793). Gale Document Number: Z2001320739, available from: http://www.gale.cengage.com/DigitalCollections/products/Burney/, accessed 27 October, 2014.

St. James's Chronicle or the British Evening Post 5601, Thursday, 14 November, (1793), Gale Document Number: Z2001321106, available from: http://www.gale.cengage.com/DigitalCollections/products/Burney/, accessed 27 October, 2014.

Star 1505, Saturday, 23 February, (1793), Gale Document Number: Z2001428930, available from: $\mathrm{http} / / /$ www.gale.cengage.com/DigitalCollections/products/Burney/, accessed 28 October, 2014.

Sun 197, Friday, 17 May, (1793), Gale Document Number: Z2001459671, available from: http:// www.gale.cengage.com/DigitalCollections/products/Burney/, accessed 29 October, 2014.

Toro Santos, A. R. de (ed.) (2000), "Introdución", in A historia d'El-Rei Breogán e dos fillos de Mil, asegún o Leabhar Gabhála. Santiago de Compostela: Museo do Pobo Galego.

Williams, S. G. and Lahaie, U. S. (2006). Socallt '05: The Year of Languages: Motivating the Language Learner with Technology. Lincoln, NE: iUniverse.

World, 2152, Wednesday, 20 November, (1793), Gale Document Number: Z2001544122, available from: http://www.gale.cengage.com/DigitalCollections/products/Burney/, accessed 30 October, 2014.

Archivo General de Simancas, 14, 17, and 26 September (1794), Secretaría de Estado. Leg.8.154. Archivo Histórico Nacional, 12 and 14 June, (1795), Estado. Leg. 8.154.

Public Record Office. National Archives. 21 June (1792). Foreign Office. Spain. Ms. 353/49.

Public Record Office. National Archives. Foreign Office. Spanish Consuls. Mss. 94/182 to 94/254.

\section{Appendix}

The session planning of this process would be organized according to the following sections:

A. Objectives:

Encourage students' knowledge of eighteenth-century history of various coun tries, namely, UK, Spain, France and USA.

Encourage students' skills in assessing online databases.

Encourage intercultural awareness.

Encourage students' perception of the existence of multifaceted aspects of reality.

Encourage students' capacity for detecting and understanding different points of view.

B. Students' Levels:

This activity is appropriate for both university graduate and undergraduate students, i.e., for upper intermediate and advanced level students. The degree of linguistic and of historic knowledge may be adapted to their competence in these issues.

The main objective is that students discover intercultural citizenship on their own, the teacher being merely a guide for them. 
C. Class Preparation:

The teacher will explain the project objectives and will make primary and secondary sources available for their exploration.

Students will deal with contemporary English newspaper analysis, particularly news sections.

Revision of various history handbooks of the period studied, published in various countries, especially in the UK and the USA.

D. Lesson Plan:

The class will be divided into four groups. Each group will represent a country and will analyse a given newspaper corpus from that perspective.

The various groups should agree as a group and within the whole class on what issues and topics must be dealt with and used as keywords in their respective searches.

They must also decide if and in what ways political issues affect the lives of people and how ideas are transmitted through the press to the respective readers. Some examples may be highlighted regarding the different ways in which the same events are transmitted or interpreted so that less interested students may be encouraged to participate.

Spokespersons from each country group will share the key events of the period and prepare group debates and a final class debate.

Individual research will also be encouraged by means of a short essay on any of the topics dealt with in their investigations.

The project will be divided into six sessions and will take place over a twoweek period.

E. Assessment:

It will be based on the students' participation and contributions in the debates, as well as on their individual essays. 
